\title{
Failure to Re-launch? \\ The United States, Nuclear North Korea, and the Future of the Six-Party Talks
}

\author{
Dr. Virginie Grzelczyk \\ Nottingham Trent University \\ virginie.grzelczyk@ntu.ac.uk
}

\section{DRAFT - PLEASE ASK FOR PERMISSION TO CITE}

\author{
Copyright (C) 2011 Virginie Grzelczyk.
}

This is a draft version that precedes the revised version published as Virginie Grzelczyk. (2012) "Failure to Re-launch? The United States, Nuclear North Korea, and
the Future of the Six-Party Talks." North Korean Review 8, no. 1.

\begin{abstract}
The United States has been involved in negotiations with North Korea for almost twenty years. During this time, American policies have oscillated between tentative engagement under the Clinton Administration to isolation and multilateralism during the Bush Administration. There has been a number of positive results, such as the signing of agreements that paved the way to a denuclearization of the Korean peninsula, but at the same time North Korea has managed, despite its apparent commitment to international agreements and in spite of international controls and safeguards, to develop and test nuclear weapons. With the Obama Administration now in place, many expected a fast resolution of pressing issues such as reprocessing, missile testing, and the hopeful replacement of the Armistice by a peace treaty. But one year away from the end of his term, President Obama has little to show in terms of results: no round of Six-Party Talks have been held under his tenure, and North Korea's multiple attacks on the South in 2010 have created new instabilities on the peninsula. Why so little result despite the promise of an era of change, away from the Axis of Evil rhetoric, military intervention and hard-line politics? This paper suggests that the Obama Administration has failed to create an original policy toward North Korea as it has pursued policies that were once successful, but under a different set of circumstances, thus leaving only bleak prospects for the resumption of the Six-Party Talks process unless Washington designs new strategies to deal with an increasingly aggressive Pyongyang.
\end{abstract}


Keywords: United States, North Korea, nuclear weapons, Six-Party Talks

\section{Introduction: Dealing with North Korea as a Balancing Act}

When president Obama took office in early 2009, there was a wave of relief amongst observers of non-proliferation that dialogue would flow again between the United States and North Korea. The history of nuclear negotiations between those two countries is long and has gone through many stages before reaching its current Six-Party Talks format. As such, after an initial period of engagement willed by President Clinton, the Bush Administration's Axis of Evil rhetoric and the United States focus on the Iraq War meant that diplomacy with Pyongyang took a back-seat, at least for a time. But despite President Bush's rather seemingly inflexible foreign policy toward North Korea, two important milestones were reached: the September 19, 2005 Agreement paved the way for parties to proceed to a denuclearization of North Korea, and the February 13, 2007 Joint Statement presented a practical plan of action for North Korea to dismantle its Yongbyon reactor.

With campaign promises hailing direct talks with North Korea leaders in his first year office, Barack Obama became President of the United States in late 2008. With the Obama Administration now in place, and coupled with a seemingly weakening and aging Kim Jong Il, stars appeared to finally be aligned to produce a rapid agreement on how to denuclearize the Korean peninsula, as well as how to improve the political stalemate that had plagued the Korean peninsula for more than fifty years. However, the Six Party Talks process has been frozen since Obama assumed office. Why such a stalemate? Has the Obama Administration fail to create a coherent foreign policy when it comes to North Korea and its nuclear weapons program, or are there other circumstances that have led to the bleakest political record between Washington and Pyongyang over the past two decades? The literature on U.S.-North Korea relations and especially in the context of nuclear disarmament efforts has essentially been divided amongst those who sought to analyze patterns of behavior and those who aimed to give prescriptions about what the United States, essentially, ought to do when dealing with North Korea. The question of what type of foreign policy should be developed by Washington in order to deal with the Korean situation is thus far from being a simple one.

On the analytical side, the literature has delineated patterns of cooperation, especially during the Clinton Administration with Litwak contending that though the concept of rogue state was a creation of the first Clinton term, North Korea was excluded from the one-size-fit-all approach toward dangerous states of not dealing with them (Litwak 2000). Despite this rogue approach, the Clinton Administration indeed decided to engage North Korea through an array of forums, discussions, and deals, thus participating in creating a 'North Korea Exception' which would then become even further acknowledged in light of the Bush Administration's military action in Afghanistan and Iraq, but not in North Korea. Other such as Albright also focused on the mechanisms that the United States had helped create in order to assist North Korea in 
denuclearizing (Albright and Hinderstein 2006). As such, the concept of CVID, or 'Complete, Verifiable and Irreversible Dismantlement' of North Korea's nuclear programs and facilities was one of the leitmotiv that came from the Bush Administration, and that also had the adverse effect of antagonizing North Korea, thus leading to its departure from the Six-Party Talks rounds a number of times. Albright suggests that the emphasis on a cooperative program of denuclearization resting on a step-by-step approach that would also utilize verification mechanisms and rewards is indeed rather different from 'non-cooperative' disarmament techniques used by the United States and especially the United Nations during the First Gulf War. The United States has also engaged North Korea through a variety of channels, and researchers such as Gordon Flake highlight efforts from non-state actors, especially NonGovernmental Organizations in the aid sectors, to revert the tendency that the United States had had over history of alienating, isolating and deterring North Korea. Indeed, Flake suggests that NGO engagement in North Korea during the Clinton Administration (and also largely supported, in many cases, by the President and his cabinet) have tipped the scales and created fundamental changes to the way the United States interacted with North Korea, as it made Pyongyang dependent on foreign aid, thus slowly curbing North Korea's behavior toward a more accommodating one in exchange for the promise of aid (Flake 2003). Though cooperation and engagement have been noted in the literature, some have also focused on negotiation strategies and have suggested that the United States has been rather unrealistic at times, especially during the Clinton Administration, and very realistic at other times such as under the Bush Administration about the true nature of North Korea's regime: indeed, Becker suggests that it would be almost criminal to ignore the vile nature of the Pyongyang leadership and especially its human righta records and crimes, and as such he criticizes figures such as Kim Dae Jung, Vladimir Putin or Madeleine Albright who had suggested, after having met North Korean leaders, that they were rational and in some cases even clever and charming (Becker 2005). But others have also suggested that the United States has at times been overly critical and strict in its approach to engagement with North Korea, especially when it came to asking Pyongyang to commit or enact a policy first in order to get a reward later: indeed, the sequential element built in many American policies toward North Korea have alienated Pyongyang from negotiations at times (Moon 2008).

On the prescriptive side and in a similar vein to the analytical one, researchers have focused on the United States developing a policy that could be anything from extremely soft to extremely unforgiving when dealing with North Korea. During the Clinton Administration, Michael Klare had already suggested that engagement with North Korea was needed, bringing about the argument that containing and isolating dangerous states would only increase their resolve against the international community (Klare 1995). More than a decade later and at the end of the Bush Administration, Martin presented similar arguments, focusing on the need for the United States to create a coherent approach to the question of North Korean nukes, and resisting the temptation to try to settle more issues such as economic sanctions, missile launch, attacks on the South and finding a resolution to the Korean conflict through encompassing and comprehensive packages. Indeed, Martin argues for a middle road approach that would do more than the current sporadic American efforts to bring about a negotiated agreement that can practically be implemented (Martin 2009). But negotiating in itself is not enough, and many support the idea that the United States often fares better when it is less inflexible in dealing with other countries. As such, there is a concerted argument calling for Washington to try to establish 
trust as well as confidence with Pyongyang by showing willing steps, that is to say for Washington to prevent from asking preconditions of North Korea, and to agree to remove a number of economic sanctions it has imposed on the North over the past decades, with some even dating from the creation of North Korea in the late 1940s (Choo 2005). Some also go further than both Martin and Choo when considering the current stalling of the Six-Party Talks, by advocating for the United States to let go of the past, and to propose new rounds of talks that do not revisit the previous deeds and misgivings of both sides. Instead, the Obama Administration should be striving for offering simultaneous solutions to North Korea instead of the traditional sequential approaches that have not proven themselves to be very successful (Park 2009). Negotiations strategies are, however, not sufficient enough for others who advocate for a more muscular approach to North Korea. Indeed, toward the end of the Clinton Administration, Henriksen for example supported the idea that international law as well as international institutions mattered when dealing with North Korea, but that the threat of a potential military intervention should also be an important component of any American Foreign Policy toward Pyongyang (Henriksen 1999). Studying negotiation patterns with North Korea, Downs also advocated for a mix of diplomatic initiatives that would require the use of military power too, thus calling for a 'stick and stick' approach instead of a 'carrots and sticks' one (Downs 1999). But despite those more hard-line approaches, there is also a general agreement in the literature that not attacking Pyongyang is by far the best course of action for the United States and Holmes suggests that Washington does not have, overall, a very good track-record when it comes to trying to solve problems by using limited war or coercive diplomatic tactics (Holmes 2006).

Given the plethora of options, tried or suggested for Washington to craft a path toward an easing of tensions with Pyongyang and by revisiting both the Clinton and Bush years, this paper suggests that Barack Obama has failed to create a coherent and original foreign policy when dealing with North Korea, largely because it had originally presented himself as being the antithesis of 'anything Bush' during the campaign. Indeed, Obama imprisoned himself in the rhetoric of accepting to sit down and talk to rogue state leaders only to backtrack a few months later, but ended up creating a foreign policy that took elements of both the Clinton and the Bush Administrations. The policy that has resulted from this pick-and-mix approach is unclear and is articulated around an inflexibility to remove sanctions, a linking of issues that create a difficult negotiating environment, a usage of track-two diplomacy that has not been focused enough on interacting with Pyongyang directly and a constant use of rhetorical tactics aimed at 'urging' North Korea to return to the talks, but without creating an environment that is likely to nurture such a return.

\section{The Clinton Years: Tentative Cooperation}

The Clinton Administration was the first American administration that was willing and that managed to engage North Korea directly. Strategies on how to deal with Pyongyang were quite varied, and it took most of Clinton's first term to find a balance in its relationship with North Korea and to create somewhat of a reciprocal relationship whereby Pyongyang would be compensated and rewarded for engaging through negotiations. Clinton's second term, however, was much more engaging toward the reclusive state, with direct diplomacy opportunities such as 
the U.S. Defense Secretary visiting Pyongyang but also offering different types of negotiation outlets such as military talks.

Though the Clinton years were always marred by the dilemma of whether North Korea should be engaged or contained, the growing concern that North Korea was refueling its nuclear reactors with the mind to eventually develop nuclear weapons led to attempts to create a framework that would allow for North Korea to receive new reactors from the international community, hence allowing Pyongyang access to needed energy, but in a more controlled environment. The 1994 Agreed Framework was the first example of creating confidencebuilding measures between North Korea and several other countries, in an attempt to reduce tensions, provide a sense of security, and at the same move toward a peaceful resolution of the Korean conflict. But the signing of the Agreed Framework was far for being a given for Kim IlSung, who was hesitant about sealing a deal, but was still interested in negotiating with the United States. His passing on July 8, 1994 marked the end to his more than five decades in power, and there was a lot of uncertainties regarding whether his son Kim Jong-Il would become the de-facto new leader, and more importantly whether he would be able to establish himself in the long-run. Incidentally, Kim Il-Sung's passing also put any talks of the Agreed Framework on hold. ${ }^{1}$ The Agreement was finally signed on October 21, 1994, thanks to the efforts of former U.S. President Jimmy Carter who practiced track-two diplomacy without informing the Clinton Administration. The Agreed Framework created incentives and step-by-step approaches for North Korea to gradually eliminate its conventional nuclear energy, while receiving oil shipments as well as two light-water reactors as replacements for the power loss.

While strategizing about North Korea's new energy development, the United States also tackled a number of issues from the past that it had been unable to discuss with North Korea until then, because of the lack of any proper channels of discussion, largely due to the fact that North Korea was not recognized by the United States, and that any direct talks would have also undermined American efforts to help protect, stabilize and develop South Korea. As such, alongside confidence-building measures and the roadmap created by the Agreed Framework, the United States tried to engage North Korea into a dialogue regarding its potential missile proliferation and testing, and also revisited some painful issues from the Korean War with the question of recovering U.S. soldiers' remains, for which Washington paid a hefty $\$ 2$ millions. Promising talks on missile proliferation also opened in late April in Berlin ${ }^{2}$ but where quickly followed by the United States imposing economic sanctions on the North after it had become known that Pyongyang had colluded with Iran on missile technology transfer. ${ }^{3}$ Despite those economic sanctions, Pyongyang appeared to remain committed to testing its missiles and kept on making preparations for an eventual launch, and it took several rounds of meetings in New York with Washington for the U.S. Department of State to eventually confirm in October that the tests had been scrapped. ${ }^{4}$

\footnotetext{
${ }^{1}$ The New York Times, "Death of a Leader; Kim Il-Sung, Enigmatic 'Great Leader' of North Korea for 5 Decades, Dies at 82," July 10, 1994.

${ }^{2}$ Pittsburgh Post-Gazette, "N. Korea Talks," April 21, 1996.

${ }^{3}$ The New York Times, "North Korea is Paid for Help on War Dead," May 21, 1996.

${ }^{4}$ Times-Picayune, "N. Korea Cancels Test of Long-Range Missile," November 10, 1996.
} 
As President Clinton moved into his second term in office, South Korean President Kim Dae Jung took control of Seoul, and announced at his inaugural speech on February 25, 1998 the broad lines of his revolutionary Sunshine Policy which was aimed at jumpstarting reconciliation between the two Koreas. The United States supported the Sunshine Policy, as it was becoming obvious that North Korea was under severe strains because of floods and droughts in the late 1990s. As such, the general idea was that a hard-collapse of the North Korean society should be avoided at all cost, thus suggesting that a soft-landing, hence a gradual collapse of North Korea would be a more suitable option for the South to absorb the North, and stability on the peninsula to be reached. Even though the United States was committed to the policy, it was also pursuing its own stick diplomacy, especially when it came to North Korea missile technology, and Washington had to impose a new round of sanctions on the North when it was discovered that some technology had been transferred from North Korea to Pakistan. ${ }^{5}$ Repeated calls by North Korea to capture financial compensations for the loss of revenue coming from its missile technology were left unanswered, ${ }^{6}$ and the United States stuck with its position of asking Pyongyang to end its missile program, especially after North Korea successfully launched its Taepodong missile into the Pacific Oceana over Japan in August 1998. ${ }^{7}$

In the late 1990s, Pyongyang focused on trying to secure security guarantees, food, and financial compensation from the international community and especially from the United States, trying to revert a desperate domestic economic situation at any cost, and being quite successful in negotiating, such as when the United States asked for access to the Kumchang-ri site as North Korea was suspected by Washington of developing secret underground nuclear facilities, ${ }^{8}$ thus being potentially in breach of the 1994 Agreed Framework: after months of back and forth talks, inspectors were finally allowed to the site, a big empty hole, in exchange for food. ${ }^{9}$ The United States also gave North Korea the option of face-to face contacts on several occasions and especially in times of crisis, such as when the North Korea and South Korean navies clashed in the Yellow Sea, leading to some progress such as North Korea deciding not to conduct new tests of its long-range missiles during the length of the Talks, in an effort to show good will and engagement with the de-escalation process. Those small successful steps were also highlighted in the Perry Report, a comprehensive assessment of various strategies in dealing with North Korea, as the report suggested that engaging North Korea through various outlets instead of alienating Pyongyang would be more likely to avoid a war.

Sensing that there might be opportunities for a momentum in dealing with North Korea, President Clinton followed Perry's recommendations, and decided to ease some of the sanctions it had imposed on Pyongyang. Being encouraged by the inter-Korea summit between Kim DaeJung and Kim Jong-Il in 2000, which also led to many North and South Korean families having the opportunity to spend some time together, a first since the partition of the Koreas in the 1940s, Washington promised to renew talks on the difficult topic of North Korea's missile program, while receiving guarantees from Pyongyang that no missile would be tested. The Clinton Administration's North Korean policy came to its apex with Secretary of State Madeleine

\footnotetext{
${ }^{5}$ The Washington Post, "N. Korea Admits Selling Missiles; Move Seen as Test of U.S. Embargo,” June 17, 1998.

${ }^{6}$ The New York Times, "Panel Says U.S. Faces Risk of a Surprise Missile Attack," June 16, 1998.

7 The New York Times, "North Korea Fires Missile over Japanese Territory,” September 1, 1998.

${ }^{8}$ Financial Times, "N. Korea Nuclear Suspicions," December 8, 1998.

${ }^{9}$ The New York Times, "Suspected North Korean Atom site is Empty, U.S. Finds," May 28, 1999.
} 
Albright's visit to Pyongyang in 2000, and her meeting with North Korean officials including Kim Jong Il. It became later known that the visit was tied to the impasse reached on many occasions on the topic of North Korean missiles, with Washington trying to 'give face' to North Korea by sending a high government representative, and possibly also planning for a visit by President Clinton following an invitation delivered by General Politburo Director Cho MyongNok in person in Washington (Gregg 2006). The momentum failed to be seized, though, as the Clinton Administration was succeeded by the Republican Bush team in early 2001.

\section{The Bush Years: From Blatant Exclusion to Multilateral Negotiations}

The Bush Administration foreign policy toward North Korea was characterized, just like the Clinton Administration, by a mixture of sanctions, incentives, as well as alienation, but was mostly notable for the use of multilateral diplomacy through the Six-Party Talks in an effort to curb North Korea's growing nuclear program, hence following on the footsteps of the largely unsuccessful Four-Party Talks that had been unable to bring about a peaceful and permanent solution to the Korean Armistice. In terms of policy at the beginning of the Bush Administration though, Secretary of State Colin Powell was quick to reaffirm that the new Administration would attempt to continue the efforts that had been made by the Clinton Administration in terms of North Korea. When South Korean President Kim Dae Jung visited Washington in the spring of 2001, though, President Bush could not commit fully to support the Sunshine Policy, as George Bush had doubts regarding North Korea's credibility and will to denuclearize. This position led to North Korea subsequently withdrawing from upcoming ministerial talks that were supposed to take place with South Korea. ${ }^{10}$

The Bush policy toward North Korea, however, took a real turn after the September 11, 2001 attacks that eventually led the United States to label North Korea as one of the Axis of Evil during President Bush's State of the Union address in January 2002. The Axis of Evil speech thus marked a departure from most of the Bush Administration's efforts to engage Pyongyang, and also ran counter to the recommendations that had been presented in the Perry report, a few years back. The Bush Administration then engaged into a hard-line policy that culminated in North Korea acknowledging it had nuclear weapons, in the reactivation of its Yongbyon reactor, in the exclusion of international inspectors, ${ }^{11}$ and in Pyongyang's withdrawal from the NonProliferation Treaty. ${ }^{12}$ If Pyongyang appeared to isolate itself from most countries and institutions, Washington also removed itself from most of diplomatic attempts and multilateral efforts, refusing North Korea's offer to freeze its nuclear program by the end of 2003 in exchange from American concessions, and flat-out turning down an offer of a bilateral nonaggression pact. Washington became also increasingly preoccupied with the situation in the Middle East as a result of the September 11, 2001 attacks and the Afghanistan strike. With the War in Iraq also raging, the Bush Administration increasingly relied on China to be a broker in the North Korea nuclear conundrum, a task that China took at heart and carried out somewhat successfully.

\footnotetext{
${ }^{10}$ The Atlanta Journal-Constitution, "Bush Fumbles Policy on North Korea," March 19, 2001.

11 The Gazette, "Pyongyang Confines Inspectors: Group Plans to Leave Country by Tuesday,” December $29,2002$.

${ }^{12}$ Financial Times, "N. Korea Quits Nuclear Non-Proliferation Treaty," April 11, 2003.
} 
One of the most contentious and contented ideas that the Six-Party Talks participants had to deal with is the 'Complete, Verifiable, and Irreversible Dismantlement' of North Korean nuclear facilities. The concept was created by the United States in the early days of the Talks, and was widely supported by South Korea (at least initially) and especially Japan which advocated for nothing short of the full application of the concept, without provision of any concession in exchange. ${ }^{13}$ North Korea rejected the wording and concept in block, and stayed inflexible when the term was used. ${ }^{14}$ The reelection of President Bush in the fall of 2004 saw a resurgence of the CVID rhetoric, with both South Korea and China being reluctant once again to use the term, as it would imply that North Korea was a nuclear state (North Korean confirmation of its uranium-enriched program would come many years later though, in 2011). But the second Bush Administration also brought about a more unified understanding of North Korea and of the necessity of pursuing multilateral negotiations: indeed, the tandem relationship between Condolezza Rice and Christopher Hill seemed to be more suitable for President Bush than the team previously formed by Colin Powel and Richard Armitage. Though CVID was not explicitly mentioned thereafter, American messages still included some aspects of it, with Christopher Hill insisting on the need to find a verifiable mechanism that included dismantlement while recognizing in a straightforward manner that the concept had somehow alienated some of Washington's allies at a time when the United States was already having little success in operations abroad such as in Iraq, for example. ${ }^{15}$

The acknowledgment in February 2005 by North Korea that it had indeed developed nuclear weapons and that it would withdraw from international forums dealing with its weapons was short-lived, however. ${ }^{16}$ Indeed, China's efforts to bring North Korea to the negotiation table, and to attempt to draft an agreement that would suit all parties resulted in the September 19 Agreed Framework. North Korea's various statements during the summer 2005 round of negotiation forced parties, however, to consider the elephant in the room: indeed, the very nature of the 1994 Agreed Framework and its provision to build light-water reactors meant that parties that had joined the consortium then had envisioned a North Korea that would be using nuclear energy for peaceful purpose. As such, the September 19 Agreement seemingly settled the nearly two-year long discussion on peaceful use of nuclear energy, and Pyongyang even agreed to international inspections, while the issue of the light-water reactors would be assessed 'at a later date. ${ }^{17}$ The celebrations were short-lived, however, as North Korea demanded, the day after the agreement was signed, for the light-water reactors to be provided before it would scrap its nuclear program, a position largely unacceptable for vociferous Japan, United States and Russia, while South Korea was more subdued when it came to Washington's refusal of the North's position. The Bush Administration stayed rather inflexible thereafter, refusing calls from North Korea to hold bilateral meetings, instead waiting for Pyongyang to return to the Six-Party negotiation table with the help of China. As the talks resumed in February 2007, a breakthrough was finally achieved with the signing of the February 13, 2007 Joint Statement, an agreement that presented a blueprint that would allow for the United States to lift financial sanctions

\footnotetext{
${ }^{13}$ United Press International, "Bolton heads strategic dialogue with China," February 16, 2004.

${ }^{14}$ Associated Press Worldstream, "North Korea calls Cheney "mentally deranged, rejects U.S. demands on nuclear programs," April 18, 2004.

${ }^{15}$ The Charlie Rose Show, "A discussion with U.S. Assistant Secretary of State Christopher Hill," October 3, 2007.

${ }^{16}$ Pittsburgh Post-Gazette, "Nuclear Admission: Talks, not Name-Calling, are the Path to North Korea," February 13, 2005.

${ }^{17}$ Agence France Presse, "South Korea welcomes North agreement," September 19, 2005.
} 
imposed on Pyongyang within a month, while at the same time asking North Korea to take steps to dismantle its nuclear facilities within a period of two months. Despite more meanders, North Korea eventually disabled parts of its Yongbyon reactor, and though it missed the December 31, 2007 deadline to submit verification materials, Pyongyang finally managed to present the documents by mid 2008, and was also rewarded by being ultimately removed from the United States list of states sponsoring terrorism

\section{The Obama Administration and the Six-Party Talks: Is there a policy?}

The change from a Republican to a Democrat administration following the late 2008 election paved the way for a seemingly new approach in terms of American foreign policy and diplomacy, with Barack Obama campaigning on dialogue and ideas of openness of discussion with leaders of all countries, including more problematic ones such as North Korea. At her Senate confirmation hearing, Secretary of State Hillary Clinton reiterated this engagement, and suggested that the previous policies that the Bush Administration had enacted toward North Korea would be comprehensively reviewed so as to craft a new approach for the Korean peninsula. ${ }^{18}$ She also firmly stated that the Six-Party Talks were an important tool that should be used in order to denuclearize North Korea.

Despite the Obama Administration's commitment to change, and the reversal of many policies and decisions that had been made by the prior Bush Administration, no new policies were enacted when it came to North Korea, and the same approach as previously used, a mix of demands for denuclearization and inflexibility when it came to the removal of economic sanctions was chosen, hence revealing a problematic aspect of the United States' commitment to the Korean peninsula. Indeed, it appears difficult to delineate a unique, new approach, as there is none, and up to a few months ago, many of the same American diplomats who had been working on the North Korean issues had stayed in posts, carried over from the Bush Administration, such as Christopher Hill, for example.

The Obama Administration focused a lot of energy and thought on strengthening and revitalizing partnerships it had with other Six-Party members such as with China, and Secretary of State Clinton also travelled in early February of 2009 to South Korea, Japan and China, expressing her support for the Six-Party talks once again. ${ }^{19}$ The diplomatic offensive also included a trip by Stephen Bosworth in March as U.S. special representative on North Korea, meeting with Chinese officials along with officials both in Japan and South Korea. The number of meetings and talks that the United States held with various Six-Party Talks partners and the nature of some of American engagements, such as planned U.S.-South Korea joint military exercises for early March irritated North Korea, as no real diplomatic overture had been made to Pyongyang, except for the reiteration of previous policies and messages pointing to the fact that North Korea had to return to the Talks first and denuclearize before any sanctions could be removed.

The North's decision to test new rocket missiles exacerbated the situation, with the United States and the other Six-Party members strongly urging North Korea not to proceed.

\footnotetext{
${ }^{18}$ Thai Press Reports, "Clinton backs Six-Party Talks for ending North Korean nuclear program,” Jan 14, 2009

${ }^{19}$ Thai Press Reports, "US Secretary of State Clinton preparing for Asia trip, counsels restraint by North Korea," February 11, 2009.
} 
From then on, most of the U.S. policies toward North Korea can be considered as being part of the 'urging' umbrella: strong rhetoric urging North Korea to stop a specific action and return to the Talks, but no real diplomatic offers apart from this one-liner. North Korea's choice to publicly withdraw from the Six-Party Talks in April of 2009 reinforced the 'urging' politics, with various figures such as Hillary Clinton publicly speaking on the need to remain tough with North Korea, while the envoy diplomacy continued, with Stephen Bosworth travelling again in May to Asia to meet China, South Korea, Japan and Russia, but not North Korea. ${ }^{20}$ Calls for North Korea to return to the Six-Party Talks continued all through the summer of 2009, with the only direct American contact with North Korea being when Bill Clinton travelled to Pyongyang to meet with Kim Jon-Il in August of 2009 to negotiate a pardon for two American women journalists, hence giving face-to-face contact with Pyongyang, a demand that had often been made by North Korea but only granted a few times over the past decades.

Trying to deflect criticism that it was maintaining a closed-door policy with Pyongyang, the U.S. Administration reiterated its calls for North Korea to rejoin the Six-Party Talks, where it would have the opportunity to converse with other partners as well ${ }^{21}$ while at the same time relying on tried Democrats such as New Mexico State Governor Bill Richardson who has nurtured contacts with North Korea for more than a decade. The message, though, was always the same: bilateral contacts are only possible through multilateral negotiations within the SixParty Talks format. Economic sanctions kept on being imposed on Pyongyang while diplomatic missions continued as well with Stephen Bosworth visiting Asia again in the fall, and then with Kurt Campbell as special envoy to China and Japan in October 2009, culminating with President Obama's 8-day Asia tour to South Korea, China, Japan and Singapore. ${ }^{22}$ Finally, after more than a year in place, the Obama Administration authorized Stephen Bosworth to have direct contacts with North Korea, as he flew to Pyongyang for a three-day trip in December.

Diplomatic efforts by China were also largely bolstered and acknowledged by the United States, as Kim Jong Il's visit to Beijing in the spring of 2010 was perceived as a potential restarter of the Six-Party Talks process. The Cheonan incident, though, derailed the minuscule progress that had been made, as the United States insisted on full resolution of the incident before any further moves could be made on the Six-Party Talks, and led to renewed scrutiny on North Korea's financial transactions, with the United States blacklisting two more North Korean entities and various individuals in an effort to cut financial support to North Korean leaders. ${ }^{23}$ Further North Korean provocations, such as the disclosure of its uranium enrichment plans as well as the shelling of the Yeonpyeong island did not alter American diplomacy much, as the Obama Administration stayed conform to the same rhetoric it has used over the past two years and carrying on into 2011: condemning North Korean provocations, calling for an end of its nuclear program, asking Pyongyang to return to the Six-Party Talks and increasing sanctions and financial scrutiny.

\section{Conclusion: Going Beyond the Stalemate, but How?}

\footnotetext{
${ }^{20}$ Thai Press Reports, "US to send envoy in bid to salvage North Korea nuclear talks," May 7, 2009.

${ }^{21}$ Xinhua General News Service, "U.S. insists bilateral talks wth DPRK in six-party framework,” August $20,2009$.

22 Thai Press Reports, “Obama pledges better future for denuclearized N. Korea,” November 172009

${ }^{23}$ Thai Press Reports, "U.S. closely watching front companies North Korea uses to evade sanctions," July 28,2010
} 
North Korea has now been engaged by the United States for almost twenty years, and there is a mixed record of achievements. On the one hand, supporters of the Sunshine Policy and of various engagement policies could argue that given the type of regime that North Korea harbors, discussions and negotiations have been rather successful at keeping Pyongyang responsive. The issue of whether the international community has failed to prevent North Korea from becoming a nuclear weapons state is, however, more complex, as it can be argue that the Agreed Framework did fall through in ensuring that Pyongyang would not divert its alleged peaceful nuclear energy to achieve other purposes. On the other hand, supporters of hard-line policy could argue that it is impossible to negotiate with North Korea as there is a strong record of defection on the part of Pyongyang, and because of the fact that North Korea is, for all purpose, a rogue state that has no intention to ever abandon its nuclear deterrent.

The Six-Party Talks have now been at a stand-still for more than two years, and the prospect for a new round of talks appears rather compromised if parties do not depart from their current positions: indeed, parties all disagree on fundamental aspects of the peaceful use of nuclear energy, how to denuclearize the peninsula, whether or not sanctions should be implemented or removed, and whether a peace treaty needs to be considered, either before or after the actual denuclearization is to take place. When considering the North Korean case, it is rather obvious that the United States and to some extent Japan are still trying to isolate North Korea and prevent Pyongyang from becoming a full-scale nuclear power. But other nations have also become de-facto nuclear powers, and other countries suspected of developing facilities such as Iran, for example, have been able to negotiate with other entities such as the European Union. It is thus perhaps time to realize that North Korea has moved on, and through testing, should now be considered a nuclear power, as argued by Kwak: this would mean that previously-agreed mechanisms and targets from the September 19, 2005 Agreement and the 2007 Joint Statement should be reevaluated in order to move the Six-Party Talks process further (Kwak 2010). Hence, it could be useful to follow Martin's suggestion that a new nonproliferation conversation should be started, and to draw on Cai's argument that considering North Korea as a nuclear power in the short-term has different implications in terms of regional powers and strategies than considering North Korea as a long-term nuclear player (Cai 2010).

The aims of the Six-Party Talks, however, are still firmly anchored in the principle of Korean denuclearization and the concept of CVID is now again used by the Obama Administration even though it was abhorred by North Korea when the Bush Administration coined it. The real question, however, is whether CVID measures are still to be considered as valid if North Korea is indeed understood as being a nuclear power. Indeed, it might be more useful to consider a spectrum of denuclearization instead of absolute goals, along the lines of Grinter, who proposes three outlooks: complete denuclearization, partial denuclearization, and collapse of talks (Grinter 2008). Doing this allows for more flexibility when talks and negotiations do not yield expected outcomes: Albright's work could be of use as it largely focuses on the cooperative aspect of the process and the various steps needed to be implemented in order to reach the utmost goal of denuclearization (Albright and Hinderstein 2006). However, such an approach is to be questioned when considering a process that has now largely become an uncooperative one. While the United States' strategy has been largely consistent since the talks' inception, with a clear understanding of steps and rewards along the way, the fact that the 
strategy has not changed while circumstances surrounding North Korea and its testing of nuclear weapons have, is problematic.

The main sticky topic at this point is the obvious relationship between sanctions, rewards, and what is expected from North Korea. The United States has been the main driver for economic sanctions, either imposing them, or refusing to remove them, and Washington has been supported by Tokyo in most instances. Coupled with the American policy of 'urging' North Korea to return to the talks unconditionally, the issue of sanctions has now led to a completely blocked process. Coercive diplomacy, however, has never been very successful for the United States as Holmes suggests, but coupled with other factors such as a domestic situation within North Korea that would leave the leadership weakened, it could lead to drastically different outcomes (Holmes 2006). But Pyongyang has already started its process of leadership transition that comes complete with domestic propaganda and political maneuvers to legitimize Kim JongUn toward both the North Korea population as well as the surrounding elite.

Choo argues that trust and confidence must be established between the United States and North Korea in order for any progress to be made, and as such he advocates for a removal of sanctions as well as bilateral and multilateral efforts to curb the situation (Choo 2005). The United States, however, has used the issue of normalization as a reward, or carrot, in the SixParty Talks process, promising an eventual consideration of the issue once more important steps related to nuclear weapons programs are taken. There has been a recent shift amongst parties, however, to consider delinking issues in order to go forward. The situation with the United States is, however, more complicated: indeed, there is an interplay between bilateral and multilateral relations, in the sense that sanctions imposed by the United States onto North Korea are done so because the United States judges North Korea's actions to be threatening to the global community, but are also interfering with the denuclearization process that is not just between Washington and Pyongyang. Are the goals of denuclearization and normalization mutuallyexclusive? Shulong supports this idea and suggests that it might be difficult for North Korea to achieve a better relationship with the United States while at the same time keeping its nuclear weapons as deterrent (Shulong 2008). Finally, the reluctance of the United States in talking to North Korea directly is far from being conducive to creating more cooperative outcomes. Indeed, the United States has a long history of negotiations and talks with North Korea over the past twenty years, and has already fared better in negotiations when it gave the face contact that North Korea always requested. Talking with all the other Six-Party Talks members through diplomatic meets is important, but North Korea is the main actor that is being targeted when it comes to denuclearization, and should therefore be consulted and listened to. One can also wonder, if there are any divisions within the Obama Administration the same way that President Bush and Colin Powell did not see eye to eye many years ago: during the 2008 campaign, sharp divisions erupted between Barack Obama and Hilary Clinton on the topic of whether the United States should talk directly to dictators. In that sense, Barack Obama has been prisoner of his initial support for the idea, and he also has been under a lot of pressure to show that he was strong enough to deal with international challenges. His inflexibility when it comes to the Korean peninsula, however, does not currently help the situation, and as such looking strong could be his downfall. Lastly, one can wonder whether one term in office is enough time to organize and maintain a coherent policy in an area that has so many uncertainties and that presents so many dangers. Both Clinton and Bush had two terms in Office to develop their 
policies, and as such, one might want to give the Obama Administration the benefit of the doubt when it comes to having had enough time to make its mark and tackle a challenging North Korea.

If no change is to be expected from the United States and the current Six-Party members, however, is there a potential for other actors to influence the situation and bring about their expertise? In this case, it might be interesting to consider the role the European Union could play in helping with the stakes. Indeed, since the beginning of the 2000s' North Korea nuclear crisis, the European Union has been more reluctant to give support to Pyongyang, as opposed to the Sunshine Policy decade. The European Union has now suspended some of its development projects until a resolution is found to the current nuclear crisis. Linking economic assistance issues and the nuclear crisis is a new step that has been taken recently, and that could contribute to the opening of a security dialogue beyond the Six-Party Talks members to include other actors. In order to do so, Brussels would most likely have to formally enter into nuclear talks through the Six-Party Talks sessions (Berkofsky 2009), but unless North Korea and especially the United states deem this to be a necessity, there is very little that it could achieve through this avenue. On the other hand, North Korea has benefitted from European economic engagement, and the idea of Europe as being more of a counterweight than before should not be dismissed (Flake 2003). Is it thus possible for Europe to play more of a constructive role in both the economic and security spheres when it comes to North Korea?

New patterns of interaction and strengthening of interactions could come from the very lack of shared history between Europe and North Korea. Comparing this situation with that of the United States and North Korea is therefore enlightening: because of the shared legacy of the Korean War as well as the fact that only an Armistice has been signed between parties, a painful historical context followed by years of distrust mean that the United States and North Korea are focused on attempting to build and rebuild trust. Brussels has the advantage of starting from a blank canvas when it comes to North Korea, and also benefits from a different understanding and approach to dealing with foreign policy crises. As such, it is historically true that Europe has been interacting with Asian countries and other nations mostly through diplomatic means, and that it has refrained from utilizing techniques such as containment and isolation, which has been used many times by the United States in the past (O'Sullivan 2000). Confidence-building measures between the European Union and North Korea could therefore lead to the establishment of a relationship in which Europe uses its plurality and transnational character in order to bring about potential solutions on how to develop the Korean peninsula, especially given the tense relationships between North and South. When looking back at the concept of the European Union, an important part of the structure of the Union was debated and created while Europe as a whole was sharply divided, with Germany not having been reunited yet and with instabilities such as those of the late 1960s in Czechoslovakia. Some supports this argument by noting that the European Union could potentially play a crucial role in the creation of a security organization that would help alleviate tensions over the peninsula, thanks to its experience in development and regional security management (Bae 2009). The European Union can also count on soft power and especially on the political clout that several of its members' former presidents and politicians possess in order to raise issues within the international community, such as a recent report that considers the concept of Responsibility to Protect and applying it to efforts, or lack thereof, of the international community toward dealing with the North Korean question 
(Havel 2008). Finally, the European Union does not possess military means but has been involved in many parts of the world through peacekeeping operations aimed at stabilizing various societies and providing relief. This technical expertise is complementary to the military might of the United States and should not be underestimated, in case of a conflict erupting over the peninsula, and leading to upsetting humanitarian issues that the U.S. Army would not be able to alleviate alone, given its current engagement in theaters, and especially in the Middle East.

\section{References}

Albright, David, and Corey Hinderstein. 2006. Dismantling the DPRK's nuclear weapons program: a practicable, verifiable plan of action. In Dismantling the Democratic People's Republic of Korea nuclear weapons program. Washington, DC: United States Institute of Peace.

Bae, Sangmin \& Martyn de Bruyn. 2009. Trust Building through Institutions: European Lessons for Korean Unification. Korea Economic Institute Academic Paper Series (1).

Becker, Jasper. 2005. Rogue Regime: Kim Jong Il and the Looming Threat of North Korea. New York: Oxford University Press.

Berkofsky, Axel. 2009. The European Union in North Korea: Player or only Payer? : Istituto per Gli Studi Di Politica Internazionale.

Cai, Jian. 2010. The Korea Nuclear Crisis and the Changing Sino-Dprk Relationship. Asian Perspective 34 (1):137-58.

Choo, Jaewoo. 2005. Is Institutionalization of the Six-Party Talks Possible? East Asia: An International Quarterly 22 (4):39-58.

Downs, Chuck. 1999. Over The Line : North Korea's Negotiating Strategy. Washington D.C: AEI Press.

Flake, Gordon L. and Scott Snyder, eds. 2003. Paved with Good Intentions: the NGO Experience in North Korea. Westport, CT: Praeger Publishers.

Gregg, Donald, Former U.S. Ambassador to the Republic of Korea. 2006. Washington D.C., $2 / 17$.

Grinter, Lawrence E. 2008. The Six-Party Talks and the Future Denuclearization and Rehabilitation of North Korea. Pacific Focus 23 (3):294-311.

Havel, Vaclav, Kjell Magne Bondevik and Elie Wiesel. 2008. Failure to Proctect: The Ongoing Challenge of North Korea. Committee for Human Rights in North Korea, The Oslo Center for Peace and Human Rights, DLA Piper.

Henriksen, Thomas H. 1999. Using Power and Diplomacy To Deal With Rogue States. Washington D.C.: Hoover Institution.

Holmes, James R. 2006. Lessons of the Korean War for the "Six-Party Talks.". World Affairs 169 (1).

Klare, Michael T. 1995. Rogue States and Nuclear Outlaws : America's Search for a New Foreign Policy. New York: Hill and Wang.

Kwak, Tae-Hwan. 2010. The Six-Party Talks and North Korea's Denuclearization: Evaluation and Prospects. Pacific Focus 25 (2):211-36.

Litwak, Robert S. 2000. Rogue States and U.S. Foreign policy: Containment After the Cold War. Washington D.C.: Woodrow Wilson Center Press.

Martin, Matthew. 2009. The Six-Party Talks and New Opportunities to Strengthen Regional Nonproliferation and Disarmament Efforts. Stanley Foundation, Korea National 
Committee on North Analysis Institute for Foreign Policy, and zu Zhongguo ren min zheng qu he ping yu cai jun xie hui. Zhongguo ke xue jia jun bei kong zhi xiao.

Moon, Chung-In. 2008. Diplomacy of Defiance and Facilitation: The Six Party Talks and the Roh Moo Hyun Government. Asian Perspective 32 (4):71-105.

O'Sullivan, Meghan L. 2000. Sanctioning 'Rogue' States: A Strategy in Decline? Harvard International Review.

Park, John S. 2009. A Proposal for A "Bosworth Process" With North Korea Denuclearization and Beyond. Washington, D.C.: Brookings Institution Center for Northeast Asian Policy Studies.

Shulong, Chu and Lin Xinzhu. 2008. The Six Party Talks: A Chinese Perspective. Asian Perspective 32 (4):29-43. 